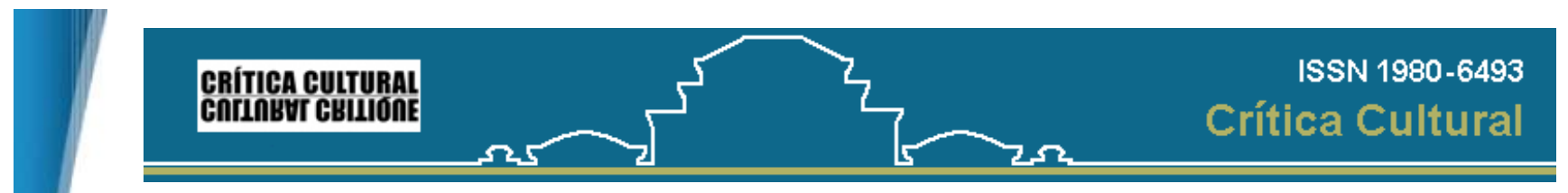

Crítica Cultural, volume 1, número 1, jan.jjun. 2006

\title{
CINEMA AND AUDIENCE: COMPLICIT PARTNERS IN CREATING CULTURAL MEANINGS*
}

Marion Gottschalk ${ }^{* *}$

\begin{abstract}
Through the analysis of a selection of texts, which explore the relation between films and audience, this essay strives to demonstrate that cultural meanings in film can be built and determined through the participation of the audience. This essay will also show how such participation reveals the diverse ways through which film can perform as a potential source for facilitating, or even preventing the cultural understanding among differing social groups.
\end{abstract}

Keywords: cinema; audience; culture; interaction

\section{STRACT:}

I promised to show you a map you say but this is a mural then yes let it be these are small distinctions where do we see it

from is the question ${ }^{[1]}$.

Adrienne Rich

Apart from being a sellable product and a source for education and enjoyment, cinema is also a means of cultural representation that through narrative can cause or deny empathy and respect among different cultures and within cultures. By requiring spectators to assume a position of interaction and reflection, the actual dialogue constructed during film viewing is dependent on the mutual, constant exchange of perspectives, opinions, concepts and beliefs between film and spectator. Film narratives raise questions about moral and ethical values as well as cultural similarities and differences. Shohat (1996, p. 179) writes, "Filmic fictions inevitably bring into play real-life assumptions not only about space and time but also about social and cultural relationships." The production of films is geographically grounded and culturally situated, and as a result, suggests a multiplicity of issues related to genre, political and economical power, ideology and national cultures.

Through an analysis of a selection of theoretical texts that explore the relationship between film and audience, this essay will demonstrate that cultural meaning within cinema may be determined through the participation of the audience. Furthermore, this essay will attempt to show how this participation reveals the diverse ways in which cinema serves as a potential source for facilitating or impeding cultural understanding between and among different social groups.

In cinematic narrative, film and spectator gradually create the relation between text and reality through the spectators' participation during the ongoing process of watching the film. This process dictates his or her subjective relation to the film and reflects his or her relation to reality. The spectator's perception of the world is reliant on his or her own experiences, opinions, emotions and images. Therefore, while watching a film, the spectator is invited to build a different reality in his mind, trying to connect and compare the film's reality with that of his own. Sinfield (1994, viii) declares that “...all cultural production operates through an appeal for recognition: 'The world is like this, isn't it?"' At times this dialogue between film and audience will provide upon the latter an awareness that its own reality does not fit into that of the film. Thereby the spectator can free him or herself from his or her own reality and may be ready to build up a new one. Cinema and audience thus exist in a fluid, shifting relationship.

It can be argued that cinema, as well as literature and any cultural production, mirrors national culture (HARRIS and HARRIS, qtd. in SPACK, 1985) and can therefore acquaint spectators with the aesthetic, moral and spiritual values of the nation and the rules of the social system (Scott, Adeyanju in SPACK, 1985). Expanding about this idea of national culture Hall declares that it is "the whole body of efforts made by a people in the sphere of thought to describe, justify and praise the action through which that people has created itself and keeps itself in existence" (121). Additionally, cinema and literature can be seen as a window to culture, helping spectators appreciate and understand other cultures (AEBERSOLD and FIELD, 1998). According to Brooks (HADLEY, 1997) culture is everything in human life and culture is the best of human life. But Seelye (in HADLEY, 1997) tries to define it broadenly affirming that culture is not only a supermarket list of factors, and it is not solely concerned with art, literature, music, history and geography. Seelye defines culture as "a broad concept that embraces all aspects of human life, from folktales to carved whales. It encompasses everything that people learn and do" (361). Thus the focus on representation, ideology, and the production of meaning constitutes, above all else, an inquiry into cultural meaning and value. As these examples from filmic and cultural theory suggest, representation can be understood as the mode in which cultural values are most effectively produced (whether to the benefit or the detriment of the viewer). Only by scrutinizing how a culture is represented and how it represents itself within cinema is it possible to understand how cinema serves as a source of meaning. Lastra (2000) argues that we are nowhere better able to track the relations between capital, science, and cultural practice than in cinema, among other areas of cultural production.

In understanding how cinema serves as a source of cultural meaning, it is essential to understand how narrative and genre create and question the role played by class, ethnicity, gender and sexuality in the shaping of cultural identities. Shohat (in STAM, 2000) points out that cinema could, "chart a map of the world, like the cartographer; it could tell stories and chronicle events, like the historiographer; it could 'dig' into the past of distant civilizations, like the archeologist; and it could narrate the customs ad habits of exotic peoples, like the ethnographer"(20). Furthermore, Stam (2000) argues that cinema's audiovisual nature offers a very rich combination of syntactic and semantic possibilities, and that with its extremely varied resources forms an ideal site for the "orchestration of multiple genres, narrational system and forms of writing" (12). He declares that even more striking is the "high density of information available to the cinema" (12). Mentioning the well-known cliché "image is worth a thousand words," Stam poses the question: "how much more worthy are the typical film's hundreds of shots (each formed by hundreds if not thousands of images) as they interact simultaneously with phonetic sound, noises, written materials, and music?" (12). Stam finally argues that by keeping these ideas in mind it is possible to conclude that cinema might be even more a powerfu medium than literature in conveying messages, ideas, and concepts. As these critics demonstrate, cinema provides a powerful source of shaping cultural identity.

In the creation of cultural meanings, interpretation can be understood as an essential process mediated by the spectator as an attempt to grasp what occurs within the narrative. Interpretation requires understanding, and understanding often requires stepping into the shoes of foreign ground and sifting through its cultural baggage, concurrently comparing and contrasting a portrayed culture versus the audience's own culture. Shohat outlines this notion, writing, "spectators (and critics) are invested in realism because they are invested in the audience's own culture. Shohat outlines this notion, writing, "spectators (and critics) are invested in realism because they are invested in the
idea of truth, and reserve the right to confront a film with their own personal and cultural knowledge" (SHOHAT, 1996, p. 178). Through this process of creating cultural meanings, cinema may then even transform reality and influence changes in history. Cinema is active in the shaping of social and individual consciousness, and thus influences the defining of cultural identities and meaning. Cinema may serve to inspire action in the spectator through the intimacy of meanings that unfold in the ongoing process of narrative unfolding. Alea (1984) expands upon this idea, writing, "...spectacle must constitute a factor in the development, through enjoyment, of the spectators' consciousness. In doing that, it moves them to stop being simple, passive (contemplative) spectators in the face of reality"(195).

Other critics further support the notion of cinema's role in the creation of cultural meanings through their discussion of the cultural role of art in general. Gombrich (in ISER, 1993, p. 7) remarks that "all art originates in our reactions to the world rather than in the visible world itself." Samuel (1985, p. 35) contributes to this argument when writing, "artistic stimuli are at men's service, i.e., the literary discourse, everything that is art, is political action." Since cinema is an expression of art, it can also be understood as a political action, touching human beings subjectively, confronting their conceptions of the world and their own position in it; consequently, cinema leads to reflection and potentially into action that may change the history within which they exist. In Hall's words, cinema cannot be theorized “...as a second-order mirror held up to reflect what already exists, but as that form of representation which is able to constitute us as new kinds of subjects, and thereby enable us to discover places from which to speak" (120).

Reader response criticism further affirms notions of cinema and the audience's essential relationship. Iser (in KOSTELNíKOVÁ, 2001) describes the reading of literary texts as "a unique activity for raising consciousness in all investigations of meaning" (85). He further claims that "a text provides 'blanks' or 'empty spaces' in the fabric of the text, which are filled according to the reader's prior knowledge" (85). These 
'gaps' or 'blanks' are basic elements for aesthetic response, demonstrating the spectator's participation. For Iser the meaning of a text is not a definable entity, but a dynamic event: it stimulates an "imaginative and creative" completion instead of a mechanical completion Sternberg (in BORDWELL, 1985) expands this idea to include cinema when characterizing a tale as 'gap-filling', where "the spectator must cooperate in fulfilling the films' form" (8). He further mentions that films, as part of an 'illusionist' craft, have raised divided opinions. He argues that some illusionist theorists usually claim that only avant-garde films can make the viewers perform 'active reading', or engage viewers in the production of meaning. For these illusionists, according to Sternberg, the Hollywood movie spectator is little more than a receptacle; he or she is not required to access any special skills of attention, memory, inference drawing or hypotheses testing. In opposition, they argue that classical films, the ones that are produced for the sake of art in opposition to the Hollywood ones that are mostly intended to be profitable, call forth some activities - like inference drawing and hypotheses testing - on the part of the spectator. Burch (in BORDWELL, 1985) defines illusion in a special way, positing, "...'illusion' is not just a matter of fooling the eye. The spectator participates in creating the illusion..." (7, italics mine). Gombrich (in BORDWELL, 1985) has also shown that "visual illusion demands that the spectator propose, test, and discard perceptual hypotheses based on expectations and probability" (8). In order for illusion to work, the spectator must meet the artwork at least halfway. "If classical cinema makes the screen a plate-glass window, it is partly because it turns a remarkably coherent spatial system into the vehicle of narrative causality; but it is also because the viewer, having learned distinct perceptual and cognitive activities, meets the film half-way and completes the illusion of seeing an integral fiction space." (BORDWELL, 1985, p. 59; italics mine) Elaborating the importance of this interaction, Iser (1993) declares that "involvement of the reader or spectator as accomplices or collaborators is essential in the curious situation of artistic communication" (4, italics mine).

As a part of this interaction, activities are required on the part of the spectator in order to participate in the completion of the narrative's building. Some of these activities are described as " classical manipulations of story order. These involve what psychologists call 'temporal integration', the process of fusing the perception of the present, the memory of the past, and expectations about the future" (BORDWELL, 1985, p. 43); here, it is evident how spectators are involved in following and creating the time order of a narrative. Film narratives also invite spectators to form hypotheses; by threading together many different hypotheses stemmed from the narrative, spectators participate in a guessing game of predicting and inferring, of expectation and probable confirmation. These hypotheses stem from gaps in the narrative and by questions openly directed at the spectator. Gaps in classical narration are usually filled by the spectator but not always. Sternberg (in BORDWELL, 1985), when discussing gaps in classical narration, distinguishes between permanent gaps, which the text never authoritatively lets viewers fill, and temporary gaps, which sooner or later will be filled. Sternberg argues that it is a basic feature of classical narration to avoid permanent gaps, in order not to frustrate or lessen the spectator's interest in the narrative. Thus, films do rely upon the same viewing activities: (i) creating and checking first impressions; (ii) linking actions by their anticipated consequences; (iii) weighing and testing alternative hypotheses about causality, time, and space. All such activities are tools to be used in the construction of the ongoing interpretation: "brick by brick, scene by scene, and inference by inference, the classical film impels the spectator to undertake a particular but not naive work" (BORDWELL, 1985, p. 69).

Considering literature, it is worth bearing in mind how literature generally leaves aspects of the narrative unexplained, some 'blanks' (ISER, 1993) to be filled by the reader's imagination. Whereas essays or newspaper articles' topics are quite clearly presented by the writer in order to be adequately understood by the reader, literature leaves much for the reader to conjecture and imagine. Nevertheless, most every author has it as his or her goal to write a story, novel or poem that will be read, enjoyed and ultimately understood by its readers. However, the author can only meet the reader halfway. There must be will and effort on the part of the reader as well, for literature (like emotion) is often dismissed under circumstances where little care is given to the art of understanding. Although the task may not be as simple as reading a news article, for example, literature and its meaning are accessible to all those with an interest in actively participating. On the other hand, the aesthetic beauty of literature, and film narratives as well, is found precisely in the fact that there is always a space left for interpretation and personal insight. "Just as no two snowflakes have ever been exactly alike, it is also true that no two people will ever see a literary passage in exactly the same light" (KELLEY, 2001, p. 2), a statement that is true for and can be applied to any art production, including cinema.

\section{REFERENCES}

AEBERSOLD, Jo Ann; FIELD, Mary Lee. From reader to reading teacher. Cambridge: Cambridge University Press, 1998.

ALEA, Tomas Gutierrez. The viewer's dialectic. In: FUSCO, Coco (Ed.). Reviewing histories - selections from new Latin American cinema. Buffalo; New York: Hallwalls, 1984.

BORDWELL, David; STAIGER, Janet; THOMPSON, Kristin. The classical hollywood cinema: film style \& mode of production to 1960 . New York: Columbia University Press, 1985

HADLEY, Alice O. Teaching language in context. Boston, MA: Heinle \& Heinle Publishers, 1997.

HALL, Stuart. Cultural identity and diaspora. pp. 110-121

ISER, Wolfgang. The implied reader. Baltimore; London: The J ohns Hopkins University Press, 1978.

. Prospecting: from reader response to literary anthropology. Baltimore; London: The Johns Hopkins University Press, 1993.

KELLEY, Stephanie A. Expanding your own English capacity through literature. New Routes. Available: <www.disal.com.br>, accessed on Sept. $24,2001$.

KOSTELNÍKOVÁ, M. et alii. Cultural awareness and language awareness based on dialogic interaction with texts in foreign language learning Strasbourg: Council of Europe Publishing, 2001.

LASTRA, J ames. Sound technology and the american cinema: perception, representation, modernity. New York: Columbia University Press, 2000.

SAMUEL, Rogel (Org.). Manual de teoria literária. Petrópolis: Ed. Vozes, 1985.

SHOHAT, Ella; STAM, Robert. Unthinking eurocentrism: multiculturalism and the media. $3^{\text {rd }}$ ed. London; New York: Routledge, 1996.

SINFIELD, Alan. Cultural politics - queer reading. London: Routledge, 1994.

SPACK, Ruth. Literature, reading, writing, and ESL: bridging the gaps. Tesol Quarterly. v. 19, n. 4, December, 1985.

STAM, Robert. Film theory - an introduction. Malden; Oxford: Blackwell, 2000.

Recebido em 20/01/05. Aprovado em 18/04/05

Título: Cinema e audiência: cúmplices na criação de significados culturais

Autor: Marion Gottschalk

Resumo: Através da análise de uma seleção de textos que exploram a relação entre filmes e audiência, este ensaio pretende demonstrar que significados culturais em cinema podem ser construídos e determinados através da participação dos espectadores. Este ensaio também procurará demonstrar como esta participação revela os diversos modos pelos quais o cinema pode atuar como fonte potencial para facilitar ou mesmo impedir a compreensão cultural entre grupos sociais diferentes.

Palavras-chave: cinema, audiência, cultura, interação.

Tìtre: Cinéma et Audience: Complicité entre partenaires dans la création de rencontres culturelles

Auteur: Marion Gottschalk

Résumé: À travers l'analyse d'une sélection de textes qui cherche à découvrir le rapport entre films et audience, cet essai a l'intention de démontrer que les significations culturelles dans le cinéma peuvent être construites et déterminées à travers la participation des spectateurs. Cet essai cherche aussi à démontrer comment cette participation dévoile les divers moyens par lesquels le cinéma peut se produire comme source potentielle pour rendre facile ou encore empêcher la compréhension culturelle entre groupes sociaux différents.

Mots-clés: cinéma; audience; culture; interaction

Título: Cinema and audience: complicit partners in creating cultural meanings

Autor: Marion Gottschalk

Resumen: Por medio del análisis de una selección de textos que se ocupan de la relación entre películas y audiencia, este ensayo intenta demostrar que significaciones culturales en cinema pueden construirse y determinarse a través de la participación de los espectadores. Este ensayo además buscará demostrar cómo tal participación da a conocer las diversas formas por las que el cine puede actuar como fuente potencial para facilitar, o aun impedir, la comprensión cultural entre distintos grupos sociales.

Palabras-clave: cinema, audiencia, cultura, interacción. 
* I would like to thank Nicholas Simonds for kindly reading and enriching this essay with suggestions.

** Professor at Universidade Regional do Noroeste do Estado do Rio Grande do Sul (UNIJUí). Master of arts' E-mail: <unijuímariong@profnet.com.br>.

[1] From Rich's "An Atlas of the Difficult World."

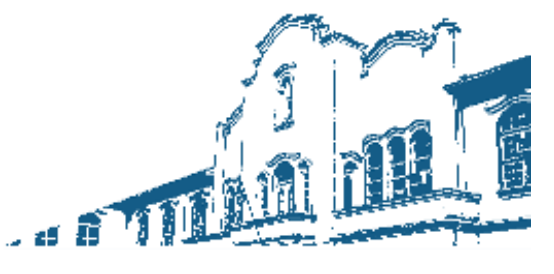

Copyright PPGCL/ Unisul 2006 @ (48) 3621-3369 - Desenvolvimento: Prof. Dr. Fábio J osé Rauen 